\title{
REREADING THE INDONESIAN INTERPRETATION OF THE QUR'AN ON AWLIYĀ': THE CASES OF HAMKA AND M. QURAISH SHIHAB
}

\author{
Abd. Kholid \\ Sunan Ampel State Islamic University Surabaya \\ a.kholid@uinsby.ac.id \\ Abu Bakar \\ Sunan Ampel State Islamic University Surabaya \\ abubakaryamani@yahoo.com \\ Muktafi \\ Sunan Ampel State Islamic University Surabaya \\ muktafi.sahal@uinsby.ac.id \\ Mukhammad Zamzami \\ Sunan Ampel State Islamic University Surabaya \\ mukhammadzamzami@gmail.com
}

\begin{abstract}
There are some problems with interpreting the verses contained in the Koran to the understanding of the contemporary Islamic age, especially regarding the issue of non-Muslim leaders. The majority of Muslim scholars argue that their religion prohibits selecting a non-Muslim leader in a normal situation. Meanwhile, few of them allow such leaders in reasonable conditions based on the argument that the prohibition in the Qur'ān and the Sunna is no longer applicable in the present life. Therefore, this paper re-analyzed the meaning of awliy $\bar{a}^{\prime}$ from
\end{abstract}


the interpretation of Hamka and M. Quraish Shihab with Jorge J.E. Gracia's hermeneutics perspective. The result suggested that the prohibition to appoint a non-Muslim as the leader is applicable only in situations where such a person shows real hostility toward Islam and makes the religion their enemy. It also applies to Muslims that violate the commands of God and His messenger because the main requirements of being a leader are the ability to create justice and foster prosperity.

Keywords: Awliyā', interpretation, Jorge J.E. Gracia, hermeneutic.

\section{A. Introduction}

Non-Muslim leadership has recently become an issue in the Muslim-majority countries, especially within the political sphere. According to Mary Silvita, some countries thatencounter this problem are Senegal, Nigeria, Lebanon (Silvita, 2012, 45). In Indonesia, some non-Muslim leaders take essential positions in the government structure, such as Susan Jasmine Zulkifli, a headman in the Lenteng Agung region of Jakarta, in 2013. Besides, a momentous political event regarding the polemic of the non-Muslim leaders in Indonesia was Joko Widodo's resignation from his position as the governor of Jakarta to become the country's president. The governorship position was replaced by the deputy, a Christian, named Basuki Tjahaja Purnama or Ahok (Dzuhayatin, 2015, 302).

Meanwhile, the existence of non-Muslim leadership in the Muslim-majority countries causes a religious debate among Muslims. This discussion also involves religious intellectuals regarding the allowance of non-Muslims to rule in Islam. The issue of making a non-Muslim the leader over Muslims is found in the Qur'ān verses, using the term awliyā'. 
This word is a plural form of walī, which epistemologically means a beloved one (al-maḥbūb), companion (al-ṣādiq), helper (al-nāșir) (Abadi, 2005, 1344), or an intimate relationship (Zakariyya, n.d., 141). The word wali and its derivations are found in approximately 234 verses in 55 surahs, while awliy $\bar{a}^{\prime}$ is found in 42 verses, specifically 23 Makkiyya and 19 Madaniyya verses (al-Baqi, 1364, 766-767).

The word awliy $\bar{a}^{\prime}$ is categorized as mushtarak or polysemy, which can mean leaders, allies, close friends, beloved ones, protectors, rulers, owners, and helpers (Setiawan, 2016, 70). Its variety of meaning is caused by the difference in its writing and speech, which determine the content (Sudarma, 2012, 97). In the al-Ma'ānī dictionary, awliyā' has several meanings such as sovereigns, leaders, or men of authority (kullu man waliya amran aw qāma bih), helpers or protectors (al-nāșir), beloved one (al-muhibb), or companion (al-șādiq). Other meanings are ally (al-haliff), family formed by marriage (al-sihhr) neighbors (al-jār), men under a commitment or covenant (al-'aqid), followers or subordinates (al-tābi), and pious people (al-muțī) (Setiawan, 2016, 70).

Referring to the Qur'ānic context where the prohibition against non-Muslim leadership occurs, the term 'leader' means a man of authority who controls a particular territory belonging to a Muslim community. The leader, in this case, is territorial and has absolute control over a Muslim region (Sudarma, 2012, 268).

On further observation, the word can mean a man who has a critical authority to make strategic decisions for the sake of all Muslims in a particular region. Hence, the area of non-Muslim dominance does not fall into this category. The 
territorial authority is an allowance to appoint a non-Muslim, providing the leader does not control Muslim territories or is involved in their strategic matters (Sudarma, 2012, 269).

Regarding the polemic of the interpretation, this research aims to share a perspective. The purpose is to reveal the variety of presentations on the allowance and prohibition to appoint non-Muslim leaders as mentioned in the several Qur'ān verses, particularly concerning those in agreement and remarkable opposition of the required conditions. Furthermore, this research aims to present a jurisprudential consequence and elaborate on the correlation between the meaning of awliya '́ and similar terms such as khalifah, amīr al-mu'minīn, imām, sulțān, and mulk in the Qur'ān.

Several existing research that share similar concern are Ismatillah et al., who studied the meaning of walì dan awliya $\bar{a}^{\prime}$ using Toshihiko Izutsu's semantic approach (Ismatillah et al., 2016; 13) and Dede Rodin in "Kepemimpinan Non-Muslim dalam Perspektif Alquran" (Rodin, 2017). Others are Hamdan Maghribi in "al-'Almanah wa al-Alāqah bayn al-Dīn wa alDawlah fī Indūnisīyā: Mawqif Nurcholish Madjid Namūdajan: Dirāsah Taḥlīlīyah" (Maghribi, 2016) and Wawan Gunawan Abdul Wahid's "Fikih Kepemimpinan Non-Muslim", in Fikih Kebhinekaan: Pandangan Islam Indonesia tentang Umat, Kewargaan, dan Kepemimpinan Non-Muslim" (Wahid, 2015). Further studies are M. Suryadinata in "Kepemimpinan nonMuslim dalam al-Qur'ān: Analisis terhadap Penafsiran FPI mengenai ayat pemimpin Non-Muslim" (M. Suryadinata, 2015), Mujar Ibnu Syarif in Presiden Non-Muslim di Negara Muslim: Tinjauan dari Perspektif Politik Islam dan Relevansinya dalam Konteks Indonesia (Syarif, 2006), and other similar research. 
This research employed Jorge J.E Gracia's hermeneutical approach1, often referred to as moderate hermeneutics, to analyze the views of two Indonesian interpreters, M. Quraish Shihab and Hamka. Sahiron Syamsuddin. Syamsuddin wrote a book entitled Hermeneutika dan Pengembangan Ulumul Quran, which stated that Gracia's "middle way" hermeneutics can integrate the objective and subjective logic of the text and the reader, respectively. The book further named Gracia's hermeneutics as the objektivis-cum-subjektivis school (Syamsuddin, 2009, 26-27). Gracia's hermeneutics can moderate two potentials of a text and reader to create a kind of balance between the authentic meaning of the text and the reader's horizon. Hence, within the spirit of a respected period, a new meaning, according to its context, can be created. The moderation emphasized the need for a balance between a search of the origin of a text and readers' role in the interpretation. In this orientation, Gracia's model of hermeneutics can be applied to the study of the Qur'ān and its exegesis.

Generally, Gracia's hermeneutic model can be called the development of textual interpretation, which builds a bridge between a historical condition, present audience, and the implication of a text. Gracia argues that three factors collaborate in the series of interpretations, which are first, text to be interpreted (interpretandum), encompassing the historicity of the text. Second, an interpreter (interpreter),

${ }^{1}$ His full name is Jorge J. E. Gracia, born in 1924 in Kuba. Gracia studied philosophy at Wheaton College and obtained his M.A at the University of Chicago. Then, he continued his Doctoral Program at the University of Toronto. Besides his formal education, Gracia spent his non-formal education in architecture (Universidad de La Habana, 1960-1961) and Study and Research (Institus d'Estudis Catalans, 1969-1970). He obtained his professorship in the Department of Philosophy, University Of Buffalo, New York. 
the person who conducts research of a historical meaning of a text and forms a new meaning and implication through the function of interpretation. Third, the addition of meaning (interpretans), a creation of the interpreter, which eventually becomes an integration of interpretandum and interpretants, or what is so-called interpretation (Gracia, 1995, 149-150).

\section{The Term Awliyā' in the Quran}

The term awliya $\bar{a}^{\prime}$ is a plural form of walī, which means 'intimacy.' The word produces its derivative meaning, such as leader, ally, close friend, follower (wala), beloved, protector, ruler, helper (wallā), and to authorize or entrust (tawallā). Generally, it can be understood as 'intimacy' created out of the relationship between the first and the second parties. However, the word wali can mean 'to stay away' (wallā 'an and look away (tawallā 'an) ) by adding the affix 'an.

The word wali and its derivative form are found in the Quran in many verses and surahs. Meanwhile, the term awliy $\bar{a}^{\prime}$ can be found, at least, in 40 verses of the Qur'ān consisting of 22 Makkiyya and 18 Madaniyya verses as shown in the table below:

\begin{tabular}{llc}
\hline No & \multicolumn{1}{c}{ Surah } & Type \\
\hline & Q.S. al-Baqarah: 257; Q.S Ali 'Imrān: 28, 175; Q.S. al- & \\
& Nisā': 76, 89, 139, 144; Q.S. al-Māidah: 51, 57, 81; Q.S. & \\
1 & al-Anfāl: 72, 73; Q.S. al-Tawbah: 23, 71; Q.S. al-Tawbah: & Madanī \\
& 71; Q.S. al-Ra'd: 16; Q.S. al-Mumtahanah: 1; Q.S. al- & \\
& Jumu'ah: 6; Q.S. al-Ahāāab: 6. & \\
\hline
\end{tabular}

Q.S. al-A'rāf: 3, 27, 30; Q.S. al-Anfāl: 34; Q.S. al-An'ām: 121, 128; Q.S. Yūnus: 62; Q.S. Hūd: 20, 113; Q.S. al2 Isrā': 97; Q.S. al-Kahf: 50, 102; Q.S. al-Kahf: 102, Q.S. alFurqān: 18; Q.S. al-'Ankabūt: 41, Q.S. al-Zumar: 3; Q.S. al-Shūrā: 6; Q.S. al-Shūrā: 9, 46; Q.S. al-Jāthiyah: 10, 19; Q.S al-Aḥqāf: 32; and Q.S. Fușșilat: 31. 
Of the 40 verses above, 42 mentions of the word awliy $\bar{a}^{\prime}$ have at least nine different meanings. First, awliya $\bar{a}^{\prime}$ as 'close friend' and 'companion' (al-șādiq) whom the believers personally confide in about their personal and public matters. This meaning corresponds with the content of several verses such as Ali Imrān: 28, al-Nisā': 76, 144, al-An'ām: 121, 128, and al-Mumtahanah ayat 1. Ibn Katsīr, in his exegesis, explained the historicity (sabab al-nuzūl) of the surah al-Mumtahanah verse 1. He recounted Hatib b. Abi Balta'ah's narration about the prophet's journey to Mecca for the sake of fath makkah (the liberation of Mecca) in the eighth Hijriyah. This verse forbids the believers to befriend and confide, especially on religious matters, in the enemies of Allah or non-believers.

Second, awliyā' as 'follower' (al-tābi'), mentioned in surah Ali 'Imrān: 175 that Allah commanded the believers to be afraid of Him only and not Satan and their followers. Third, awliyā' as 'helper,' 'protector,' and 'supporter' (al$n \bar{a} s ̦ i r$ ), obtained from the inferred message of the verses such as surah al-Nisā': 89, 139, al-Māidah: 57, 81, al-Anfāl: 72, 73, Hud: 20, al-Isrā': 97, dan al-'Ankabūt: 18. The helpers in these verses are the people who help and take care of the believers' needs. Regarding surah al-Nisā': 89, al-Ṣābūnī in his Șafwat insisted that this verse is about the ban on handing over religious matters (tawallā) and befriending the munāfiqūn (hypocrites) before they embrace their belief by hijrah (return to Islamic teaching) and conduct jihād in Allah's way (al-Ṣābūnī, 1997, Vol. 1, 271).

Fourth, awliyā' meaning 'protector,' inferred from the verses, al-Ra'd: 16, al-Baqarah: 257 (protector or leader), alA'rāf: 30 (protector or ally), al-Zumar: 3, al-Shūrā: 6, 9, 46, 
al-Ahqāf: 32, and Fușșilat: 31. Being a protector means to fulfill and maintain the believers' need in the world and the hereafter like Allah, as Ibn Katsīr explained. Allah commands his angels to protect and guide believers to His commands in the world and accompany them to their graves after they die. He also commands the angels to protect them on the judgment day (yawm al-ba'ts) and lead them to pass sirāt al-mustaqìm (the straightway) to heaven (Ibn Katsīr, Vol. 2, 1999, 210).

Fifth, awliyā' as 'lover' (al-muhib) or 'close friend' (al$\left.a^{\prime} w a \bar{n}\right)$, mentioned in surah al-Jumu'ah: 6. Al-Ṣābūnī argued that the term in this verse means Allah's lover, and as mentioned in the subsequent verse, contradicted the Jews' claim that they are the sons of Allah and the ones He loves the most (al-Ṣābūnī, Vol. 3, 1997, 355).

Sixth, awliyā' as 'brothers' (ikhwān) and 'family' (alusrah), including blood and foster brothers, as written in surah al-Tawbah: 23 and al-Aḥāb: 6. These verses, according to Ibn Katsīr, captured the brotherhood of muhājirin and anșār unified by Prophet Muhammad. The practice of this brotherhood-as narrated by Ibn 'Abbās—makes inheriting the wealth of a non-blood family possible. Also, they were revealed to revise the law (naskh) and permit them to only help their foster brothers (awliyā') in good things (Ibn Katsīr, 1999, Vol. 6, 447-449).

Seventh, awliyā' as 'a sovereign' (al-mawlā), obtained from surah al-Anfāl: 34. Ibn Katsīr clarified that the verse is about the time Quraysh infidels impeded the muttaqin (the believers) from praying in the Masjid al-Haram (The Great Mosque of Mecca). This action gave the impression that they were the sovereigns of Mecca when instead, the Muslims had 
the right, as authorized by Allah, to worship, including salāt and țawāf, where Ka'ba is its direction (Ibn Katsīr, 1999, Vol. 4, 36).

Eighth, awliyā' as 'the worshipped' (al-ma'būd), mentioned in surah al-Furqān: 18 and al-Jāthiyah: 10. AlȘābūnī accounted that polytheists, on the day of judgment, will be gathered with what they worshipped-'Isa, 'Uzair, and angels, whom Allah would ask whether they misled God's servants to worship them. Then, they would answer that nothing deserved to be worshipped than Allah (al-Șābūnī, Vol. 2, 1997, 327).

Ninth, awliyā' as 'the leader' (al-muwālah), a meaning obtained from surah al-Māidah: 51, al-A'rāf: 3, 27, dan alKahf: 50. Ibn Katsīr explained these verses that Allah forbids his servants to make infidels their leader. Hence, infidels are prohibited from taking an essential role in knowing and leading secret matters, details, and the teaching of Muslims (Ibn Katsīr, 1999, Vol. 3, 106-107). ${ }^{2}$ The ban is also for the practice of mutual help, making or being close friends, and mu'āsharah (having relations) with the infidels (al-Ṣābūnī, Vol. 1, 1997, 322). This prohibition ensures that Muslims do not return to their previous error after the faith. Moreover, Allah prohibits his servants from helping his enemies, which are the infidels (al-Ṣābūnī, 2008, 283).

Based on the verses above, the meaning of awliy $\bar{a}^{\prime}$ is related to intimate relationships between Muslims and infidels through friendship, mutual help, or leadership, which

${ }^{2}$ The leader can also be defined as the important person in charge in the governmental sector based on the narration of Ibn Abi Hatim from 'Iyad that 'Umar snapped and smacked the thighs of Abu Musa al-'Asy'ari, who appointed a Christian secretary while quoting surah al-Māidah 51. 
are forbidden by God. The reasons are, first, the intimate relationship with infidels may unveil Muslims' secrets and harm them. Second, handing over any matters to infidels is inappropriate because it may cause Muslims to lose faith and return to their error. Third, infidels persuade people to become involved in hypocrisy and mistakes. Consequently, this persuasion is supposedly avoided by Muslims as it lacks any goodness and advantages.

\section{B. Interpretations of the Term Awliy $\bar{a}^{\prime}$}

Some mufassir (commentators) interpreted awliyā' as 'the leader' and specified surah al-Māidah: 51 as the verse containing this contextual meaning. Subsequently, the two commentators named Hamka and M. Quraish Shihab discussed here were selected because of the significant influence in their life periods as the mufassir and their knowledge of the archipelagic horizon.

\section{B. 1 Hamka's Commentary}

In his commentary, al-Azhar, Hamka translated the word awliyā' in surah al-Māidah: 51 as "the leaders." Meanwhile, this commentator brought in the cause of this verse's revelation while holding onto the prominent theory among Muslim intellectuals. This theory states that "to draw a conclusion and generate the meaning and message of a verse, one has to see a general intention, not the particular cause in which the verse was revealed." Furthermore, he believed that the prohibition was applicable as long as the intention was to maintain the interest of Islam. 
Hamka, while translating the verse, commented that "the first command clearly says that believers bear a consequence because of their beliefs. Once they admit to being believers, they should not take Jews and Christians as leaders or offer them secret information concerning Muslims' interest, for that is not a solution but a new problem." In addition, Hamka stated that "the important concern is how the Qur'ān called them Jews and Christians rather than the noble name of ahl al-kitāb, meaning the people of the book. Experts in balāghah (linguistics) of the Qur'ān argued that calling them people of the book is inappropriate by stating, "Do not make the people of the book as your leaders." The reason is the God's books revealed to them do not contradict the teaching of Tauhid (monotheism) brought by Prophet Muhammad PBUH. He added that they will realize the previous books are not contradictory to the Qur'ān after releasing themselves from fanaticism ( $t a^{\prime} a s ̦ s ̦ b$ ). However, since they hold their sectarian pride and call themselves Jews and Christian, they ignore Islam (the submission to God) and have chosen the wrong way." 3

${ }^{3}$ A possible question can be posed to his argument: can the followers of Judaism and Christianity today be called the people of the book? His explanation above means that calling them the people of the book is inappropriate because they embraced a faith contradictory to the oneness of God, hence they should be called Jews and Christians instead. Hamka did not seem to deliberately mean that since the majority of Ulema agreed on calling the Jews and Christians the people of the book despite their deviations from the teachings of Moses and Jesus as mentioned in the Qur'ān, "They are not the same" (Q.S. Ali 'Imrān [3]; 113). Moreover, aren't we convinced that the deviated people of the book are persuaded to meet in the kalimat sawa', that is the oneness of God (to not worship except God), as written in surah Ali 'Imrān [3]: 64? Does the allowance to eat their foods and marry their girls not exist today, as agreed by Hamka in his explanation above, although they still embrace trinitarianism? Allah also calls them the people of the book and forbids those who exaggerate against their beliefs and religiosities (surah al-Māidah [5]: 77). 
Furthermore, Hamka firmly stated that the verse is the prohibition for Muslims to appoint Jews and Christians as the leaders. The next verse, "whoever makes them leaders amongst you, verily, they have become one of them," is seen by Hamka as crucial because persons who appoint, sympathize, tend to like, and are similar to them. He wrote," they are not the followers of the unbelievers' religions through their sympathy. However, 'Abd alHumaid narrated that a statement from a companion of the prophet Hudhaifah bin al-Yaman, "walyattaqi ahadukum an yakūna yahūdiyyan aw nașrāniyyan wa huwa lā yash'urū." Meaning: be cautious that each of you might become Jews and Christians without realizing it" (Hamka, Vol. 3, 1982, 1763).

He proceeded with the explanation, "This verse emphasizes that the prohibition is on appointing the unbelievers to be leaders, yet we are not forbidden to build human-to-human interactions or relationships with them. For instance, independent Muslim countries like our nation currently need to participate in economic activities, and we are not going to isolate ourselves from such interactions." Then, he quoted the verse al-Hujurāt: 13 by writing, "we the Muslims are allowed to marry girls from ahl al-kitāb without them embracing Islam as their religion because the leader of the family is the husband, not the wife. However, experts on Islamic jurisprudence argue that an ordinary Muslim man cannot marry a girl from ahl al-kitā b because the leader is the husband, who must be embracing and knowledgeable about Islamic teaching." This is the commentary on surah al-Māidah: 51 in Hamka's work al-Azhar. 


\section{B. 2. M. Quraish Shihab's Commentary}

In interpreting surat al-Māidah: 51, M. Qurasih Shihab related it (munāsabah) to the previous verse. Shihab wrote, "If the Jews and Christians or whoever, are as portrayed in the verses al-Māidah: 49 and 50, that they tend to follow the jāhiliyya law and ignore the law of God, and provoke Muslims to turn against some of God's revelations, then 0 believers! Do not take easily nor with effort, the Jews, Christians, and those like them, as awliy $\bar{a}^{\prime}$ (allies). Their attitudes are the same in their ignorance and hatred toward you, and some of them are allies of one another. Although their religions and faiths are different, they face you because of their interest, which, in this case, is the same" (Shihab, Vol. 3, 2012, 149).

Quraish proceeded to discuss the key term in verse. Although the word tattakhidhū mentioned in the verse linguistically means 'to take,' it can have a different meaning, according to the following verse. Although the translation of the Qur'ān by the Religious Department gives the word awliya ' the meaning 'leaders' after the phrase la tattkhidhū, this, according to Quraish, is not always the case. Awliyā' is a plural form of wali, which generally means 'intimate,' with later derivatives signifying 'supporter,' 'defender,' 'protector,' 'lover,' 'the priority,' and so on. He exemplified that the walī, in this case, her blood parents, has the right to legalize the marriage of a girl because there is an intimacy between them and their daughters. The pious people can also be called wali due to their closeness with God. In addition, awliy $\bar{a}^{\prime}$ can also mean the leader(s), who is close to the 
lead. Hence, the lead confides problems in the leader because of the sense of intimacy, who then, because of the closeness, answers the complaint (Shihab, Vol. 3, 2012, 151-152). Quraish cited the al-Tabataba'i argument regarding the term awliyā' as,

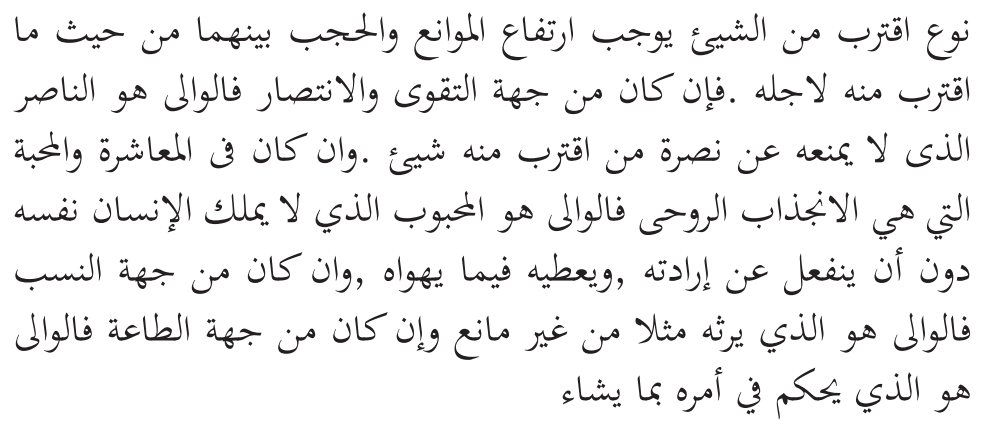

"A form of intimacy toward something that makes the veils between the two parties disappear is the goal. In the context of piety and mutual help, al-wali means the helper who is not hindered from helping and being close to anyone. Also, concerning al-mu'āsharah (interaction), compassion, or something that contains an attraction to the soul, al-wali means love, which makes fulfilling someone's command not difficult. In the family context, al-wali means "a son" who inherits and not hindered, while based on obedience, al-wali means somebody who rules or the leader who has to be obeyed" (al-Tabataba'i, Vol. 5, 1998, 378).

Quraish also cited the argument of Muhammad Sayyid Tantawi, stating that the prohibition to making Jews and Christians awliy $\bar{a}^{\prime}$ is not generally applicable. The reason is that Jews and Christians during that period were divided into three groups. First, those who live, maintain the peace, do not fight, and do not show any 
hateful behaviors against Muslims, making them have the same rights and social obligations as the religious. Second, those who fight or harm Muslims by any means. The religious are forbidden to have harmonious relationships or approach them, and this is the group captured by the surah al-Māidah: 51. Third, those who are secretively against Muslims but do not sympathize with the enemy of Islam. Allah commanded the believers to be cautious toward them without being hostile (Shihab, Vol. 3, 2012, 153-154).

Quraish confirmed that the word käfir, in the case of the prohibition, means the people who do not embrace Islam. However, the Qur'ān interprets the word to involve those who ignore the oneness of God, do not obey His commands and are ungrateful for His blessing. Hence, kāfir, in this case, refers to all activities that ignore the commands of God and His messenger, and avoiding such people, either Jews, Christians, or even Muslims, is obligatory.

Regarding the three classifications above, according to Quraish, Muslims are commanded to be kind to the first group and give them the same rights and obligations as they have. Conversely, they are instructed to be careful of the second and third groups and not make them friends (Ibid).

\section{Jurisprudential Consequence and the Correlation between the Meaning of Awliy $\bar{a}^{\prime}$ and Related Terms}

The meaning of Awliyā' as 'leaders' is problematic due to its related terms. Some of the associated words in the Qur'ān are al-Khalīfah, al-Mulk, al-Sultān, al-Imām, dan Amīr al-Mu'minin. 


\section{1. Al-Khalīfah in the Qur'ān}

The word al-Khalifah is derived from the root khalafa-yakhlufu, meaning 'to replace.' Its plural form is khalä'if or khulafä', and the meaning is used in the context of authority, such as to replace one leader with another. The legitimate leader after the period of the prophet is called khalifah, as he inherits the mission to spread Islam. Allah used the same word to address a man that can lead the Earth. Meanwhile, Ibn Katsīr commented on the meaning of khalifah in surah al-Baqarah: 30, "A group of people to replace other groups, period after period, generation after generation," then quoted surah al-An'ām: 165 (Ibn Katsīr, 1999, Vol. 1, 100). The word khalīfah is mentioned eight times in the Qur'ān, located in al-Baqarah: 30, Ṣād: 26, al-An'ām: 165, Yūnus: 14 dan 73, Fāțir: 39, al-A'rāf: 68 dan 73, and al-Naml: 62 (alMuqaddasi, 2016, 135).

\section{2. Al-Mulk in the Qur'ān}

Al-Mulk epistemologically means 'having an authority or power over something' (Zakariyya, Vol. 5, n.d., 351). Al-Mulk can also mean 'to own or control,' when taken from the root word malaka, or 'he owns and controls the thing,' when inserted into a sentence, like "malaka al-insān al-shay'a." It has been used to name a leader in charge of a particular territory (mālik). On this meaning, Al-Ṭabarī interpreted surah Ali 'Imrān: 26, “Yā man lahu mulk al-dunyā wa al-ākhirah khālișan dūna ghayrahu-0! the absolute owner of the worldly kingdom and the kingdom in the afterlife, nothing except Thou" 
(al-Ṭabarī, 2008, 299). The word al-Mulk is mentioned in the Qur'ān 16 times, and some are located in the surah al-Baqarah: 247, al-An'ām: 73, al-Haj: 55, al-Furqān: 62, Fāțir: 13, al-Taghābun: 1, al-Mulk: 1, and Ali 'Imrān: 62 (al-Muqaddasi, 2016, 414-415).

\section{C.3. Al-Sulțān in the Qur'ān}

Al-Sultān is derived from the root sultah, which epistemologically means power and sovereignty and shows one's power over other people. Therefore, the controlled people will follow his lead and execute the sovereign's command. Ibn Katsīr explained the meaning of al-Sulțān in surah al-Hijr: 42 as - Indeed, My servantsno authority will you have over them, except those who follow you of the deviators-, "To the people whom I (Allah) give the guidance, you (Satan) will never find a way to control them and you will never reach them" (Ibn Katsīr, 1999, Vol. 5, 14). The term al-Sulțān is mentioned in 19 verses of the Qur'ān, some of which are al-Hijr: 42, al-Naḥl: 99, al-Ṣaffāt: 156, al-A'rāf: 70, Yūnus: 68, Hūd: 97, Yūsuf: 40, Ibrāhīm: 10, 11, 22, al-Kahf: 15, and al-Naml: 21 (al-Muqaddasi, 2016, 217).

\section{C.4. Al-Imām in the Qur'ān}

The word al-Imām was initially to call the leader in salāt. Imām can also mean the man who is followed and whose need is fulfilled (Zakariyya, Vol. 1, n.d., 82). AlImām as the leader is mentioned in the Qur'ān and based on the surah al-Anbiyā': 73, al-Ṣābūnī wrote: 


$$
\text { جعلناهم قدوة ورؤساء لغيرهم يرشدون الناس إلى دين بأمر الله }
$$

"We made them (Ibrahim, Ishaq, dan Ya'qub) role models and heads of the other (groups of people), who lead the human to the right path as the order of Allah" (al-Șābūnī, 1997, Vol. 2, 245).

The word al-Imam and its plural form a'immat are found in 13 verses of the al-Qur'ān, including alTawbah: 13, al-Anbiyā': 73, al-Qașșaș: 5, 41, al-Isrā': 71, al-Baqarah: 124, al-Māidah: 3, Yāsin: 12, and al-Hijr: 79 (al-Muqaddasi, 2016, 32).

\section{The Reconstruction of the Meaning of Awliy $\bar{a}^{\prime}$ Using Gracia's Hermeneutics.}

This reconstruction uses Gracia's interpretation function, and this part of the discussion will elaborate on the additional meaning of this work by using three features viz. historical, meaning, and implicative functions.

\section{D.1. The Historical Function of the Word Awliy $\bar{a}^{\prime}$}

This sub-chapter discusses the historical meaning understood by audiences about the prohibition of nonMuslim leadership mentioned in surah al-Māidah: 51, revealed before the liberation of Mecca (fath makkah). The verse is related to the case of 'Ubādah bin Samit and 'Abd Allah bin Sallūl, which narrated that "'Ubadah broke away-of the mutual help agreement-from the Jews who showed enmity to Allah and His messenger. 
Al-Ṭabarī, al-Jazāirī, and al-Zuhaylī agreed that the narration is the story behind the revelation of surah alMāidah: 51, while al-Tabarī doubted the interpretation. The prohibition (highlighted here) happened because the Jews and Christians began to show their hostility toward Islam, and this enmity, according to Hamka, was their nature. Consequently, the people who believe in Allah and His messenger are prohibited from cooperating with such groups of infidels.

As written in surah al-Māidah: 51, the word awliy $\bar{a}^{\prime}$ was mentioned after the imperative sentence "la tattakhidū al-Yahūda wa al-Nașārā." Therefore, the general meaning, according to al-Ṭabarī and Hamka, is that believers are prohibited from taking Jews and Christians as awliy $\bar{a}$ ', either as 'leaders,' 'helpers,' 'close friends,' and other relationships that indicate intimacy between Muslims and Jews and Christians. Therefore, this intimacy was the cause of the ban.

Some reasonable factors are, first, some Muslims still had weak faith, leading to the worry that those with close relationships with the groups against Islam would be affected and return to their wrong path. Second, the hostility toward Islam is the nature of Jews and Christians, as argued by Hamka, and relationships between Muslims and the people against them are illogical. Al-Zamakhshari commented on surah al-Māidah: 51 in the following sentences:

$$
\text { لا تتخذوهم أولياء تنصروفم وتستنصروفم وتؤخوفم وتصافوفم وتعاشروفم }
$$


"Do not take the Jews and the Christians as allies (awliyā'), that is, do not appoint and help them, do not ask for their help, do not make them brothers, and do not interact with them as you interact with the believers" (al-Zamakhshari, Vol. 2, 2013, 249). He continued, "the prohibition, as Allah explained, is because some of these people awliya $\bar{a}^{\prime}$ for others among them and are unified in their denial. Why should a man do a muwālah with people from a different religion?" This is how AlZamakhshari wrote and criticized the intimacy with Jews and Christians.

He also commented on the verse, "And whoever is an ally to them among you - then indeed, he is [one] of them." This is the legal provision for them, and Al-Zamakhshari highlighted it:

$$
\begin{aligned}
& \text { وهذا تغليظ من الله وتشديد في وجوب مجانبة المخالف فن الدين واعتزاله }
\end{aligned}
$$

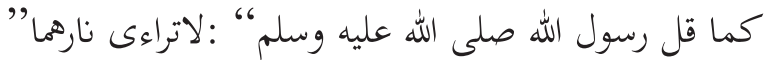

"This is a taghlizz4 from Allah and the enforcement and obligation to avoid people with different religions as the prophet said: "Showing no fire (used to cook) by two parties, between the Jews and Christians on one side and Muslims on the other" (al-Zamakhshari, Vol. 2, 2013, 249).

Al-Zamakhshari quoted the saying, which was falsified as 'Umar b. al-Khattāb's words by Abū Musa al-Ash'ari, who is a Christian. However, the sentence is

${ }^{4}$ Taghlīz is to use words or certain situations to emphasize something, though the literal meaning of the words is not meant by the speaker. 
different from the narration by al-Wahidi. Al-Zamakhshari instead narrated this version: "Do not respect them for Allah has insulted them! Do not trust them because Allah stated that they have betrayed, and do not approach them because Allah has dissociated them.".

The implication of the verse "ba'duhum awliya" $b a^{\prime}$ ' $^{\prime \prime}$ is to disassociate from the Jews and Christians because only their people are supposed to befriend them. Then, the next verse stated that everyone who helps (yatawallā) the Jews and Christians is one of them regardless of the religion he embraces. The other reason behind the prohibition is that, as stated by al-Qurțubī, muwālah cannot be justified according to syara' and the relationship must end. Al-Qurțubī explained, "al-yahūd wa al-nașārā in surah al-Māidah: 51, is the object of the verb "la tattakhidhū" (al-Qurțubī, Vol. 8, 2016, 46-47). The explanation on this has been elaborated in surah Ali 'Imrān: 28 and 118. Concerning surah Ali 'Imrān: 28, al-Qurțubi quoted the statement of the prophet's companion, Ibn 'Abbas, that the prohibition means:

$$
\text { اعتبروا الناس بإخوافم }
$$

"Look at a man-judge him-from whom he befriends" (al-Qurțubī, Vol. 8, 2016, 46-47).

This narration, according to al-Qurțubī, is in line with the content of Ali 'Imrān: 188, which is the

${ }^{5}$ al-Zamakhshari means, "Accept that your writer is dead, then do all you have to do at the time now and look for a successor! Indeed, Allah does not give His guidance to people who tyrannize themselves by building intimacy with infidels. 
prohibition to muwālah (build intimacy) with people outside Muslims (al-Qurțubī, Vol. 5, 2016, 273).

At first, al-Qurțubī described the meaning of bițānah used as the synonym of awliyā' in surah Ali 'Imrān: 21 and 51. According to him, bițānah refers to whoever is judged and considered the special man, with whom all the secrets are shared (al-Qurțubī, Vol. 5, 2016, 272). After that argument, al-Qurțubī wrote:

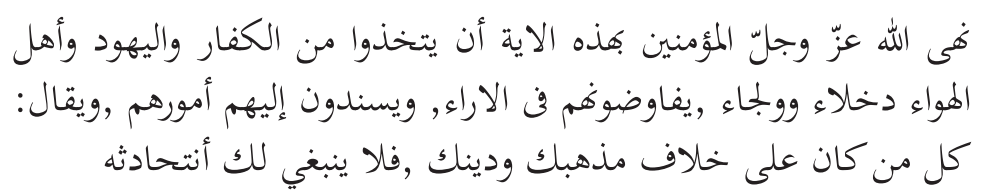

"Through this verse, Allah the Almighty forbids believers to take and involve the infidels, Jews, and those who have been controlled by their carnality into the Muslim community, using negotiation and hearing their arguments. The saying that "discussing with everyone from different paths and religions as you, is unreasonable" is true (alQurțubī, Vol. 5, 2016, 272).

Furthermore, al-Qurțubi clarified that the people meant by the verse are the hypocrites, as it says, " $O$ the believers of only the outlook." Indeed, they build intimacy by sharing Muslims' secrets. There is another opinion, wrote al-Qurțubi, that this verse was revealed in the case of Abū Lubābah, as well as other opinions that take a part of Ibn Jarīr al-Ṭabarī's argument. Al-Qurțubī further explained that the phrase-ba'duhum min $b a^{\prime} d$ shows the legal provision on the relatedness between Jews and Christians that they have inherited to each other. 
Then, al-Qurțubi continued with the phrase, "And whoever is an ally to them among you-that is, whoever supports them to harm Muslims, then indeed, he is [one] of them." Allah set the legal provision of allies as the same as for Jews and Christians, hindering them from obtaining the inheritance from Muslims because they are apostates. Regarding the disassociation, the legal provision lasts to the hereafter, and regarding this context, al-Qurțubi quoted surah Hūd: 113 and Ali 'Imrān: 28, 118 (alQurțubī, Vol. 8, 2016, 47).

Al-Qurțubī commented, "the verse - and whoever is an ally to them among you-then indeed, he is [one] of them, is its condition and effect because the individual is against Allah and His prophet just like Jews and Christians. Hence, the obligation against them is the same as that against Jews and Christians, and they deserve hellfire similarly" (al-Qurțubī, Vol. 8, 2016, 48).

The explanation above shows the clarity of the prohibition to making Jews and Christians awliyā', whether as 'leaders,' 'helpers,' 'close friends,' and so on. This is because they are the enemies of Allah that fight Him, His prophet, and Muslims. Moreover, such intimacy with non-Muslims could potentially unveil their secrets and harm Islam. Also, the closeness creates sympathy that may cause people with weak faith to return to their wrong path. Although the disassociation is for the Jews and Christians who physically show hatred toward Islam, Muslims are allowed to have a good relationship with those who do not show enmity to the religion. 


\section{2. The Meaning Function of Awliy $\bar{a}^{\prime}$}

This part of the discussion elaborates on the meaning function and development related to the prohibition to making Jews and Christians allies (awliyā'). The meaning function is an effort to reconstruct the interpretation of surah al-Māidah: 51 and apply it to the present life while holding to the substantive historical meaning as the logical limit.

As previously addressed, the prohibition is limited to Jews and Christians who show enmity toward Allah, His messenger, and all the believers. Quraish confirmed Muhammad Rashid Rida's argument that the verse was revealed because of the non-believers' bad attitude toward Muslims at that time, based on the three group divisions. First, the Jews and Christians living harmoniously with the Muslims. Since this group did not intend to rebel nor have a bad justification toward Muslims, they are granted the same rights and obligations (Shihab, Vol. 3, 2012, 153-154).

Second, the group against Muslims, with which the religious are prohibited from building intimate relationships. Surah al-Māidah: 51, Qurasih Shihab insisted, is meant for this group. Then, he quoted surah al-Mumtahanah: 9 (Shihab, Vol. 3, 2012, 153-154).

Third, the group secretly against Muslims, who, despite their enmity toward Islam, did not help or sympathize with the enemies of Islam. Quraish stated that the Muslims should be cautious of this group without showing hostility toward them. 
Then, Quraish commented, "the verse - And whoever is an ally to them among you-then indeed, he is [one] of them-indicates that faith has levels. Some of the people living with the prophets had weak faith and possessed a degree of doubt, though they were not necessarily hypocrites who showed their faith but hid their infidelities. Nevertheless, they were still called believers despite their doubts in their hearts, which was an illness that led them to build good relationships with the Jews and Christians. Their doubt also made them worry about experiencing calamities. They were the people the Qur'ān called the men with an illness in their hearts." Then, Quraish quoted the verse, "Indeed, Allah does not give His guidance to the unjust people." According to this commentator, the verse does not say that Allah does not deliver religious guidance to people who have illness in their hearts, however, He does not lead them to happiness (Shihab, Vol. 3, 2012, 154-155).

Quraish stated that this could be the case regarding the meaning of awliyā' as 'the leaders.' However, he interpreted it as intimacy, which makes the unification between the two parties possible and renders keeping their secrets and distinguishing between them difficult. For this commentator, the context of prohibition stated in al-Māidah: 51 is the disassociation from the people who were against Muslims. The reason is that mașlahat ummat al-Muslimin is supposed to be prioritized above others.

Based on the context of revelation, as stated by Quraish, the verse is a command to disassociate from nonMuslims who showed hostility to Islam, and appointing 
non-Muslim, in that case, is forbidden. However, the development from the verse is the allowance to build good relationships with non-Muslims who are not against Islam and appoint them as leaders in that consideration. This attitude was exemplified by the prophet and Muslims toward the Jews who were supportive of Islam. Hence, the non-Muslims who are supportive of Islam are granted the same right and obligations as the Muslims, including in the leadership.

Furthermore, the meaning of al-Māidah: 51 can also be developed into an understanding that muwālah is not only limited to non-Muslims who are against Islam. Instead, it extends to the fāsiq, who are Muslims that violate Allah's commands, as such persons do not bring any advantages to Islam. Building intimacy with the fāsiq will undoubtedly cause a Muslim to violate God's command, therefore appointing such leaders cannot be justified based on the contextuality and meaning of surah al-Māidah: 51.

\section{3. The Implicative Function of Awliy $\bar{a}^{\prime}$}

After discussing the historical meaning and development of surah al-Māidah: 51 while maintaining its substantive meaning, the last stage of Gracia's hermeneutics is the implicative function. As stated by Gracia, "The implication of the text meaning is derived from the meaning based on other principles" (Gracia, $1995,111)$. The purpose of this function is to inform the audience about the implication of the meaning of awliya $\bar{a}^{\prime}$. In this case, the implicative function of the word is limited 
in its meaning as 'leaders.' Therefore, the focus of this article is on the allowance of non-Muslim leadership in Muslim-majority communities.

As previously discussed, the reason behind the prohibition to building an intimate relationship with Jews and Christians was because these groups showed hostility to Islam and were against it. Therefore, creating good relationships with this kind of non-Muslims only brought disadvantages to Islam. Another reason was that the faith of some Muslims in that period was weak. Some of the prophet's companions built the relationship with the Jews because they were afraid of possible calamities, like during the defeat of Muslims in the Uhud war. Hence, failing to make this relationship forbidden would likely cause such Muslims to return to their infidelity. Hamka and Quraish's argument that building an intimate relationship with Jews and Christians emotionally would make the difference and distinction between Muslims and non-Muslims disappear or difficult indicates that religiosity was crucial in one's identity during that period. The reason is that people were identified by the religions they embraced i.e., Islam, Judaism, and Christianity.

In a global and pluralistic context such as Indonesia today, the ethnic-religious disputes that were resolved by Prophet Muhammad until the "Constitution of Medina" was finally formed must be learned. This constitution is a peace agreement and a draft law that regulates the plurality of communities and various sectors of life in Medina, including political, social, legal, economic affairs, human rights, equality, religious freedom, defense, 
security, and peace. The constitution contains one power in the form of one ummah (ummah wähidah) and includes the rights and procedures regarding conflict resolution and community action for Muslims (Muhājirīn and Anșār) and non-Muslims. Modern Muslims believe that these documents and experiences in Medina can be a guide for a pluralist socio-political system that follows tradition and Islamic revelation (Zamzami, 2011, 97-98).

Through this charter, Prophet Muhammad introduced a harmonious and peaceful community system for the people of Medina and laid the foundation of a strong life to form a new ummah, namely a peaceful and harmonious civil society. The Medina people came from at least three different groups, namely Muslims from the Muhājirīn and Anșār groups as the majority, non-Muslims from the Aus and Khazraj tribes, who had not converted to Islam as a minority, and the Jews.

Presently, one's identity is not based on his religious affiliation but his nationality, which the government legalized by establishing the identity card, called KTP in Indonesia. This nationality or citizenship card owned by each individual in the country is to grant them their rights and obligations and ensures each individual is free to live and communicate with other citizens. Religion, then, is no longer the binding identity of the citizens, neither is race nor tribe (Kamali, 2009, 121-123). The reason is that everyone is equal before the law regardless of ethnicity, religiosity, race, and group (SARA).

Regarding Indonesia as a nation and not a religious state, no individual with a non-Muslim status cannot run 
for leadership in a Muslim-majority country. There is no dhimmi (the people of the covenant) term in a nationstate model (Anjum, 2016, 31-40). Perhaps the view of Tariq al-Bishri (d. 2021), an Egyptian Muslim thinker, in a book entitled al-Muslimūn wa al-'Aqbāt fí Ițār al-Jamā'ah al-Wațaniyah (Muslims and Copts in the Framework of the National Community) needs to be considered. Bishri tried to emphasize the importance of appreciating the Coptic Christian community amidst Muslims. In the name of nationalism in Egypt, he stressed the importance of avoiding sectarian divisions to achieve unity in the country (Bishri, 1981). Also, Fahmi Huwaidi, in his book Muwāținūn lā Dhimmiyūn: Mawqi' Ghayr al-Muslimīn fi Mujtama' al-Muslimin (Citizens, not Dhimmis: The Place of NonMuslims in the Society of Muslims), tried to contextualize the Islamic idea of citizenship contemporarily. For Huwaidi, the classical concept of dhimmī, though workable in the classical Islamic era, can no longer be used today. Therefore, Muslims cannot escape from a completely different new reality where the basis of "membership in a country" is determined by the principle of nationality, not religion (Huwaidi, 2005). The view that a Muslim has two non-contradicting and non-negating citizenships, one centered on Islam that unites him to all other Muslims, and the other on one's land of birth and residence, should be agreed upon (Bishri, 1988, 17).

Moreover, a modern nation governs all aspects of social life by establishing national laws, including on presidential elections. Although a religious country requires the candidates to be Muslims based on the 
sharia laws, secular nations adopt constitutional laws that do not depend on any religious affiliation. Therefore, using verse al-Māidah: 51 as the prohibition to take non-Muslims as the leaders cannot be justified, though Muslims are the majority in the nation.

Besides, the obedience to the nation and its established policies, alongside the involvement to maintain unity, is the obligation of Muslims as long as Allah and His messenger's commands are not violated.6 The obedience to the legal government will create unity, the ability to minimize personal or communal conflict, and prosperity for all citizens. This is believed to be the purpose of Islam, as written in surah al-Anbiyā': 92, Ali 'Imrān: 103, and al-Anfāl: 46.

In the previous discussion on the meaning function through its development, the context in which the prohibition in surah al-Mā'idah: 51 occurred was nonMuslim hostility toward Islam and Muslims' violation of Allah and His messenger's commands. However, the destruction of Islam nowadays is from external and internal factors, as not all Muslims are obedient to the command of Allah and His messenger, and not all put religious interests above personal matters. Some of them mind their interests and seek worldly pleasures, hence appointing such Muslims as leaders is not the right choice because they do not bring advantages to the religion.

${ }^{6}$ The command for obedience to the legal ruler is mentioned in surah al-Nisā': 59. However, there is a debate between those who agree based on the assimilation of al-din wa al-dawlah (religion and state) and those who distinguish them (no correlation between religion and state). In this case, the argument that Muslims should be obedient to the government that leads its citizens to justice and prosperity is preferred because there is no clear explanation of the type of state system Muslims should obey. 
Regarding the election of a leader, al-Mawardi gave seven necessary characteristics. They are (1) being a just man, (2) knowing to perform ijtihād to deal with problems and religious laws, (3) having good five senses. (4) Physical health, (5) being able to deal with the problem of the people and foster the common good, (6) being brave in defending the people and facing enemies, (7) originate from the tribe of Quraisy (al-Mawardi, n.d., 5). These requirements are mostly related to the prosperity principle, and since not all the elements can be obtained, the most required are justice and the ability to foster the prosperity of the people.

The power of leadership lies, according to Ibn Taymiyah in al-Siyāsah al-Shar'īyah, in the knowledge of justice and law enforcement. He also stated that responsibility is the fear of Allah, not infidelity to attain a position and personal interest or fear of humans, as mentioned in surah al-Māidah: 44.

Moreover, Ibn Taymiyah wrote that the unity of power and responsibility in an individual is difficult. For instance, assuming there are two men, where the first has a higher responsibility and the second has higher power, one is selected according to the position and duty he can bear. In the leadership of the war, the bravest and most knowledgeable of strategies is prioritized. Although such a person is a fäjir (insubordinate), he is the better option than the more pious but physically weaker man. The reason is that the first man benefits the people, and his infidelity affects himself, while the weak leader endangers the people, and his piety is for only himself. In this case, Ibn Taimiyah quoted the prophet's saying: 
"Indeed, Allah supports this religion through an insubordinate man" (Bukhārī). In the other version, "...through a group, which does not have goodwill to create religious prosperity."

Based on the analysis, the prohibition to appoint non-Muslims as leaders is not generally appropriate but can be applied to those who make Islam their enemy. The prohibition can also be the reverse, as Muslims that violate Allah and His messenger's commands cannot be leaders because one of God's commands is the will to create justice and foster prosperity of the people.

\section{E. Conclusion}

Some people think Islamic countries during the caliphate are examples of ideal countries. However, after intensive study, there is no single example of an ideal Islamic state other than during the Medina al-Munawwarah period, which lasted only 25 years. Subsequently, there was simply an expansive and greedy form of government until the end of the Ottoman Turkish caliphate. No country is touted as an 'Islamic state' that deserves to be imitated other than Medina with all its specifications, which no country has ever emulated. Unfortunately, the existence of this state cannot be repeated, as there is no guarantee that Muslim leaders are always good.

The majority of Muslim scholars argue that religious members are prohibited from selecting a non-Muslim leader in a normal situation, while a few allow such individuals in reasonable conditions. This allowance is based on the argument that the prohibition of non-Muslim leadership in the Qur'ān and Sunnah is no longer presently applicable. 
Meanwhile, Gracia's moderate hermeneutics approach was used to analyze the interpretation of Hamka and M. Quraish Shihab. The result suggested that the prohibition to appoint a non-Muslim as a leader is only applicable, given that the individual shows real hostility toward Islam and makes the religion their enemy. Also, the prohibition is for Muslims that violate the commands of God and His messenger, as the main requirements of being a leader are the ability to create justice and foster the prosperity of the people.

\section{References}

Abadi, Muhammad b. Ya'qub al-Fayruz (2005). al-Qāmūs alMuhịț. Beirut: Muassasat al-Risālah.

Anjum, Ovamir (2016). Dhimmi Citizens: Non-Muslims in the New Islamist Discourse. ReOrient, Vol. 2, No. 1. doi:10.13169/reorient.2.1.0031

Baqi (al), Muhammad Fuad 'Abd. (1364). Mu'jam Mufahras li Alfāz al-Qur'ān al-Karīm. Cairo: Dār al-Kutub al-Mișrīyah.

Bishri (al), Tariq (1998). Bayn al-Jāmi'ah al-Dīnīyah wa alJāmi'ah al-Wațanìyah fì al-Fikr al-Siyāsī. Cairo: Dār alShurūq.

Bishri (al), Tariq (1980). al-Muslimūn wa al-'Aqbāt fí Ițār alJamā'ah al-Wațaniyah. Cairo: al-Hay'ah al-Mișrīyah al'Āmah li al-Kitāb.

Dzuhayatin, Siti Ruhaini (2015). “Islam, Kepemimpinan NonMuslim, dan Hak Asasi Manusia", in Wawan Gunawan Abdul Wahid, dkk (eds.), Fikih Kebhinekaan. Bandung: Mizan Pustaka. 
Gracia, Jorge J. E. (1995). A Theory of Textuality: The Logic and Epistemology. Albany: State University of New York Press.

Huwaidi, Fahmi (2005). Muwāținūn lā Dhimmiyūn: Mawqi' Ghayr al-Muslimīn fī Mujtama' al-Muslimīn. Cairo: Dār al-Shurūq.

Ismatillah, Hasyim, A. Faqih., dan Maimun, M. (2016). "Makna Wali dan Awliya' dalam al-Qur'ān: "Suatu Kajian dengan Pendekatan Semantik Toshihiko Izutsu", Diya al-Afkar, Vol. 4, No. 2.

Kamali, Mohammad Hashim (2009). "Citizenship: An Islamic Perspective", Journal of Islamic Law and Culture, Vol. 11, No. 2. https://doi.org/10.1080/15288170903273060

Maghribi, Hamdan (2016). “al-'Almanah wa al-'Alāqah bayn al-Dīn wa al-Dawlah fī Indūnisīyā: Mawqif Nurcholish Madjid Namūdajan: Dirāsah Taḥlīlīyah". QIJIS: Qudus International Journal of Islamic Studies, Vol. 4, No. 1. DOI: http://dx.doi.org/10.21043/qijis.v4i1.1600

Mawardi (al), Abu al-Hasan 'Ali b. Muhammad (2006). alAhkām al-Sulțānīyah wa al-Wilāyah al-Dīnīyah. Kuwait: Maktabah Dār Ibn Qutaybah.

Muqaddasī (al), 'Ilmī Zādah Fayḍ Allah al-Hasanī (2016). Fath al-Raḥmān li Ṭālib Āyat al-Qur'ān. Beirut: al-Ahliyyah, 2016.

Qurțubī (al), Abu 'Abd Allah Muhammad b. Ahmad (2016). al-Jāmi' li Ahkeām al-Qur'ān, Vol. 8. Cairo: Muassasat alRisalah.

Rodin, Dede (2017). "Kepemimpinan Non-Muslim dalam Perspektif Alquran” Mutawâtir: Jurnal Keilmuan Tafsir Hadis, Vol. 7, No. 1. 
Șābūnī (al), Muḥammad Alī (2008). Rawāi' al-Bayān: Tafsīr Àyat al-Aḥkām, Vol. 1. Beirut: Dār Ibn 'Abūd.

Ṣābūnī (al), Muhammad 'Ali (1997). Ṣafwat al-Tafāsir, Vol. 1. Beirut: Dar al-Fikr.

Setiawan, Khoirul Himmi (2016). Makna Awliya'. Tokyo: Lakpesdam NU.

Shihab, M. Quraish (2012). Tafsir al-Mishbah. Jakarta, Lentera Hati.

Silvita, Mary (2012). "Presiden Non-Muslim dalam Komunitas Masyarakat Muslim”, Islamica: Jurnal Studi Keislaman, Vol. 7, No. 1. DOI: https://doi.org/10.15642/ islamica.2012.7.1.44-60

Sudarma, Fatimah Djaja (2012). Semantik 1: Makna Leksikal dan Gramatikal. Bandung: Rafika Aditama.

Suryadinata, M. (2015). “Kepemimpinan non-Muslim dalam al-Qur'ān: Analisis terhadap Penafsiran FPI Mengenai Ayat Pemimpin Non-Muslim", Jurnal Ilmu Ushuluddin, Vol. 2, No. 3.

Syamsuddin, Sahiron (2009). Hermeneutika dan Pengembangan Ulumul Quran. Yogyakarta: Pesantren Nawesea Press.

Syarif, Mujar Ibnu (2006). Presiden Non-Muslim di Negara Muslim: Tinjauan dari Perspektif Politik Islam dan Relevansinya dalam Konteks Indonesia. Jakarta: Pustaka Sinar Harapan.

Tabarī (al), Ibn Jarīr (2008). Jāmi' al-Bayān an Ta'wil Āy alQur'ān, Vol. 6. Beirut: Dār Hajar li al-Ṭibā'ah wa al-Nashr. Ṭabāțabā'ī (al), Muhammad Ḥusain (1997). al-Mīzān fì Tafsīr al-Qur'ān. Beirut: Muassasat al-A'lamī li al-Maṭū'āt. 
Wahid, Wawan Gunawan Abdul (2015). "Fikih Kepemimpinan Non-Muslim", in Fikih Kebhinekaan: Pandangan Islam Indonesia tentang Umat, Kewargaan, dan Kepemimpinan Non-Muslim". Bandung: Mizan Pustaka, 2015.

Zakariyya, Ahmad b. Faris b. (1979). Mu'jam Maqāyis alLughah, Vol. 6. Beirut: Dār al-Fikr.

Zamakhshari (al), Abu al-Qasim Mahmud b. 'Umar (2013). alKashshāf, Vol. 2. Beirut: Dār al-Ma'rifah.

Zamzami, Mukhammad (2011). "Islam Sebagai Agama dan Umat: Analisa Pemikiran Kenegaraan Jamâl al-Bannâ". Teosofi: Jurnal Tasawuf dan Pemikiran Islam, Vol. 1, No. 1. https://doi.org/10.15642/teosofi.2011.1.1.93-112. 